\title{
Data report: late Eocene-early Oligocene ostracods at IODP Site U1411, off Newfoundland, North Atlantic ${ }^{1}$
}

\author{
Tatsuhiko Yamaguchi
}

\section{Chapter contents}

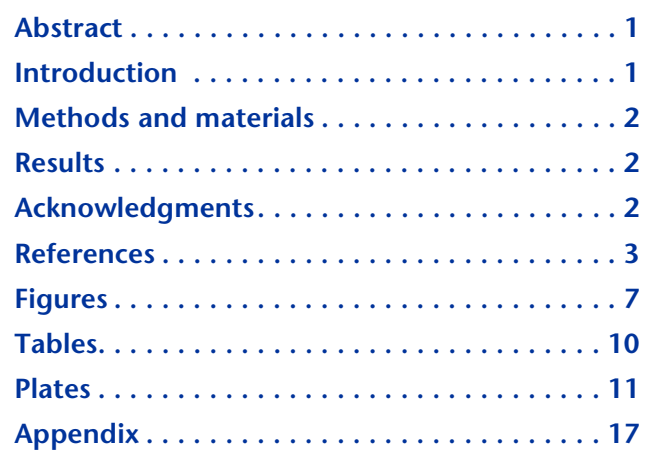

'Yamaguchi, T., 2018. Data report: late Eoceneearly Oligocene ostracods at IODP Site U1411, off Newfoundland, North Atlantic. In Norris, R.D., Wilson, P.A., Blum, P., and the Expedition 342 Scientists, Proceedings of the Integrated Ocean Drilling Program, 342: College Station, TX (Integrated Ocean Drilling Program). doi:10.2204/iodp.proc.342.206.2018

${ }^{2}$ Center for Advanced Marine Core Research, Kochi University, Nankoku 783-8502, Japan.

tyamaguchi@kochi-u.ac.jp

\section{Abstract}

At the present, typical North Atlantic Deep Water ostracod faunas are characterized by the dominance of Krithe species and the association with Henryhowella and Poseidonamicus. The fauna may have originated during the Eocene-Oligocene. Because there are only a few taxonomic studies on Eocene-Oligocene ostracod taxa in the North Atlantic deep-sea sediments, the ostracod taxa are poorly understood. Here I report and illustrate 23 taxa from the upper Eocene-lower Oligocene sediments at Integrated Ocean Drilling Program Site U1411 in the North Atlantic Ocean and describe the taxa systematically.

\section{Introduction}

Under the North Atlantic Deep Water (NADW), modern ostracod faunas are characterized by Krithe, Poseidonamicus, Henryhowella, and Abyssocythere (Dingle and Lord, 1990). Benson (1975) named the faunas with Krithe, Poseidonamicus, Henryhowella, and Abyssocythere as the psychrosphere fauna and considered that it appeared during the Eocene-Oligocene transition. Using foraminifer stable isotope and $\mathrm{Nd}$ isotopes, some studies hypothesize that the NADW was initially formed during the early Oligocene (e.g., Via and Thomas, 2006; Katz et al., 2011). The formation of the psychrosphere fauna is being argued (e.g., Dall'Antonia et al., 2003), but it may be linked to the formation of NADW. Because some of the characteristic taxa originated from the early Paleogene, the psychrosphere fauna may have been formed before the late Eocene (e.g., Steineck et al., 1984; Guernet and Bellier, 2000). In the North Atlantic Ocean, the Eocene-Oligocene ostracods are poorly understood, with only limited data (Ducasse and Peypouquet, 1979; Coles and Whatley, 1989; Whatley and Coles, 1991; Coles et al., 1994; Coles, 1996; Guernet and Bellier, 2000) (Fig. F1). Previously, Coles and Whatley (1989) described 3 new genera and 21 new species from the upper Eocene to lower Oligocene sediments at Deep Sea Drilling Project (DSDP) Sites 549, 550, and 558. Coles et al. (1994) studied the taxonomy and biostratigraphy of the genus Krithe in the North Atlantic Ocean and proposed 4 new taxa of Krithe from the upper Eocene to lower Oligocene sediments at Sites 549 and 550. Guernet and Bellier (2000) reported 51 taxa from the upper Eocene sediments at Ocean Drilling Program (ODP) Sites 1052 and 1053. Here, I report and illustrate 23 taxa of 
late Eocene-early Oligocene ostracods from Integrated Ocean Drilling Program (IODP) Site U1411, off Newfoundland in the North Atlantic Ocean. At IODP Site U1407, Yamaguchi et al. (2017b, 2017c) already reported and described 32 ostracod taxa from Maastrichtian-Thanetian sediments.

\section{Methods and materials}

At Site U1411 $\left(41^{\circ} 37^{\prime} 5.94^{\prime \prime} \mathrm{N}, 48^{\circ} 59^{\prime} 59.94^{\prime \prime} \mathrm{W}\right)$, three holes were drilled on the seafloor of the southeast Newfoundland Ridge at $3299 \mathrm{~m}$ water depth (see the "Site U1411" chapter [Norris et al., 2014]; Fig. F1). We took 39 sediment samples of $\sim 20 \mathrm{~cm}^{3}$ volume from the working halves of Cores 342-U1411B-16X through 28X (Table T1). All the core sediments consist of two lithologic units: silty clay with nannofossils at 140-235 $\mathrm{m}$ core composite depth below seafloor (CCSF) and nannofossil chalks with foraminifers at 235-266 m CCSF (lithostratigraphic Units II and III, respectively). The sediments are pinkish to white in color. Using planktonic biostratigraphy, the core sediments are dated to be $~ 37.9-$ 33.4 Ma, late Eocene to early Oligocene, and correlate to nannofossil Zones NP18-NP21 of Martini (1971) and foraminiferal Zones E14-O1 of Wade et al. (2011). The paleodepth at $34 \mathrm{Ma}$ is estimated to be around $3000 \mathrm{~m}$.

For extracting ostracod specimens, we washed samples using a sieve with $32 \mu \mathrm{m}$ openings. Ostracod specimens were picked from fractions $>150 \mu \mathrm{m}$ using a fine brush under a binocular microscope. The specimens were observed and their photos were taken with a JSM-6500F scanning electron microscope (SEM) (JEOL Ltd.) (Pl. P1, P2, P3, P4, P5) and an optical microscope in order to identify them to the species level and describe morphological characteristics.

For illustrating the internal structures of the new species, the specimens were immersed in tap water in a Petri dish and observed under transmitted light on a VHX-2000 digital microscope (Keyence, Ltd.). Images of the internal structures were also captured. Using the focus stacking system equipped with the digital microscope, deep-focus images of the internal structures were made (Pl. P6). Image outlines were drawn to identify shapes of marginal pore canals and vestibulum (Fig. F2). Valve length and valve height of the specimens were measured using the digital microscope (Table T1, T2; Fig. F3). The SEM and the digital microscopes are hosted at the Center for Advanced Marine Core Research at Kochi University (Japan).
For systematic descriptions, higher taxonomy followed Brandão et al. (2017). The general terminology of the morphology followed Sylvester-Bradley and Benson (1971) and Horne et al. (2002). The terminology for characteristics of Krithe and trachyleberids followed Coles et al. (1994) and Yasuhara et al. (2015), respectively. According to Athersuch et al. (1989), carapace size is classified as follows:

Small: $<500 \mu \mathrm{m}$ long

Medium: 500-650 $\mu \mathrm{m}$ long

Large: $>650 \mu \mathrm{m}$ long

All the specimens were registered and deposited at the National Museum of Nature and Science (NMNS) (Tsukuba, Japan) and the Scripps Institution of Oceanography (SIO) (University of California, San Diego), which are Micropaleontological Reference Centers for the International Ocean Discovery Program (Table T1). The catalog numbers at NMNS and SIO have prefixes of MPC and SIO-BIC, respectively.

\section{Results}

Preservation of the specimens is good overall. The specimens are translucent to white in color; some have secondary calcite. External structures, such as carinae, spines, and reticulation, are well preserved. Calcareous ooze and nannofossils are attached to the surface of the specimens and often cover muscle scars and pores. We identify 23 taxa that belong to 2 suborders (Platycopida and Podocopida) and 12 families (Bairdiidae, Bythocyprididae, Bythocytheridae, Cytherellidae, Cytheruridae, Eucytheridae, Krithidae, Loxoconchidae, Paracytherideidae, Pontocyprididae, Trachyleberididae, and Xestoleberididae) (Table T3). The Krithidae and Trachyleberididae taxa are diversified, with six species each. See the Appendix for taxonomic notes.

\section{Acknowledgments}

This research used samples provided by the Integrated Ocean Drilling Program (IODP). We are grateful to Yoshimi Kubota (NMNS) and Charlotte Seid (SIO) for their help to register and deposit the specimens, Hiromi Takeda (Kochi University, Japan) for his help to capture SEM images, and Gene Hunt (Smithsonian Institution National Museum of Natural History) for his critical review and constructive comments. This study was financially supported by the IODP Expedition 342 After Cruise Research Program of the Japan Agency for Marine-Earth Science and Technology and by JSPS KAKENHI Grant Num- 
ber JP16K05590 of the Japan Society of Promotion of Science.

\section{References}

Alvarez Zarikian, C.A., 2009. Data report: late Quaternary ostracodes at IODP Site U1314 (North Atlantic Ocean). In Channell, J.E.T., Kanamatsu, T., Sato, T., Stein, R., Alvarez Zarikian, C.A., Malone, M.J., and the Expedition 303/306 Scientists, Proceedings of the Integrated Ocean Drilling Program, 303/306: College Station, TX (Integrated Ocean Drilling Program Management International, Inc.). http://dx.doi.org/10.2204/ iodp.proc.303306.213.2009

Alvarez Zarikian, C.A., 2015. Cenozoic bathyal and abyssal ostracods beneath the South Pacific Gyre (IODP Expedition 329 Sites U1367, U1368 and U1370). Palaeogeography, Palaeoclimatology, Palaeoecology, 419:115-142. http://dx.doi.org/10.1016/j.palaeo.2014.07.024

Angue Minto'o, C.M., Bassetti, M.A., Morigi, C., Ducassou, E., Toucanne, S., Jouet, G., and Mulder, T., 2015. Levantine intermediate water hydrodynamic and bottom water ventilation in the northern Tyrrhenian Sea over the past 56,000 years: new insights from benthic foraminifera and ostracods. Quaternary International, 357:295-313.

https://doi.org/10.1016/j.quaint.2014.11.038

Athersuch, J., and Horne, D.J., 1984. A review of some European genera of the family Loxoconchidae (Crustacea: Ostracoda). Zoological Journal of the Linnean Society, 81:1-22.

https://doi.org/10.1111/j.1096-3642.1984.tb02557.x

Athersuch, J., Horne, D.J., and Whittaker, J.E., 1989. Marine and Brackish Water Ostracods: Avon (Bath Press).

Ayress, M.A., Barrows, T., Passlow, V., and Whatley, R., 1999. Neogene to Recent species of Krithe (Crustacea: Ostracoda) from the Tasman Sea and off southern Australia with description of five new species. Records of the Australian Museum, 51(1):1-22. https://doi.org/10.3853/j.0067-1975.51.1999.486

Baird, W., 1850. The Natural History of the British Entomostraca: London (The Ray Society). https://doi.org/10.5962/bhl.title.1807

Benson, R.H., 1972. The Bradleya problem, with description of two new psychrospheric ostracode genera, Agrenocythere and Poseidonamicus (Ostracoda: Crustacea). Smithsonian Contributions to Paleobiology, 12:1-138. https://doi.org/10.5479/si.00810266.12.1

Benson, R.H., 1975. The origin of the psychrosphere as recorded in changes of deep-sea ostracode assemblages. Lethaia, 8(1):69-83. http://dx.doi.org/10.1111/j.15023931.1975.tb00919.x

Bergue, C.T., Costa, K.B., Dwyer, G., and Moura, C.A.V., 2006. Bathyal ostracode diversity in the Santos Basin, Brazilian southeast margin: response to late Quaternary climate changes. Revista Brasileira de Paleontologia, 9(2):201-210.

Bergue, C.T., and Nicolaidis, D.D., 2012. The PaleoceneOligocene ostracodes from DSDP Site 329 (Falkland Pla- teau): taxonomy and paleozoogeographical remarks. Paleontological Research, 16(1):47-58.

https://doi.org/10.2517/1342-8144-16.1.047

Bergue, C.T., Nicolaidis, D.D., and Andrade, K.N., 2013. The lower Eocene-lower Oligocene ostracodes from DSDP Site 515B, Brazil Basin, southwestern Atlantic Ocean. Revista Brasileira de Paleontologia, 16(1):27-38. https://doi.org/10.4072/rbp.2013.1.02

Blow, W.H., 1969. Late middle Eocene to Recent planktonic foraminiferal biostratigraphy. Proceedings of the First International Conference on Planktonic Microfossils, 1:199-422.

Bowen, R.N.C., 1953. Ostracoda from the London Clay. Proceedings of the Geologists' Association, 64(4):276-292. https://doi.org/10.1016/S0016-7878(53)80036-2

Bornemann, J.G., 1855. Die mikroskopische Fauna des Septarienthones von Hermsdorf bei Berlin. Zeitschrift der Deutschen Geologischen Gesellschaft, 7:307-371. https://biodiversitylibrary.org/page/34850378

Brady, G.S., 1868. A monograph of the recent British Ostracoda. Transactions of the Linnean Society of London, 26(2):353-495. https://doi.org/10.1111/j.10963642.1968.tb00199.x

Brady, G.S., Crosskey, H.W., and Robertson, D., 1874. A monograph of the post-Tertiary Entomostraca of Scotland including species from England and Ireland. Palaeontographical Society Monographs, 28:1-232. https://doi.org/10.5962/bhl.title.84825

Brandão, S.N., Angel, M.V., Karanovic, I., Perrier, V., and Yasuhara, M., 2017. World Ostracoda Database. http://www.marinespecies.org/ostracoda

Bubikyan, S.A., 1958. Ostracoda from Paleogene deposits of the Erevan Basin. Izvestiya Akademii Nauk Armyanskoy SSR, Seriya Geologiya-Geografiya, 11:3-16. (in Russian; original title translated)

Coles, G., 1996. A preliminary ostracod zonation for the Cenozoic deep water North Atlantic. In Keen M. (Ed.), Proceedings of the 2nd European Ostracodologists Meeting, Glasgow 1993, 86-92.

Coles, G., and Whatley, R., 1989. New Palaeocene to Miocene genera and species of Ostracoda from DSDP sites in the North Atlantic. Revista Espanola de Micropaleontologia, 21(1):81-124.

Coles, G.P., Whatley, R.C., and Moguilevsky, A., 1994. The ostracod genus Krithe from the Tertiary and Quaternary of the North Atlantic. Palaeontology, 37(1):71-120.

Cronin, T., and Compton-Goodin, E., 1987. Cenozoic Ostracoda from Deep Sea Drilling Project Leg 95 off New Jersey (Sites 612 and 613). In Poag, C.W., Watts, A.B., et al., Initial Reports of the Deep Sea Drilling Project, 95: Washington (U.S. Government Printing Office), 439-451. https://doi.org/10.2973/dsdp.proc.95.116.1987

Dall'Antonia, B., Bossio, A., and Guernet, C., 2003. The Eocene/Oligocene boundary and the psychrospheric event in the Tethys as recorded by deep-sea ostracods from the Massignano Global Boundary Stratotype Section and Point, Central Italy. Marine Micropaleontology, 48(1-2):91-106. https://doi.org/10.1016/S0377-8398(02)00163-9 
Dingle, R.V., 1981. The Campanian and Maastrichtian Ostracoda of south-east Africa. Annals of the South African Museum, 85:1-181.

Dingle, R.V., and Lord, A.R., 1990. Benthic ostracods and deep water-masses in the Atlantic Ocean. Palaeogeography, Palaeoclimatology, Palaeoecology, 80(3-4):213-235. http://dx.doi.org/10.1016/0031-0182(90)90133-R

Do Carmo, D.A., and Sanguinetti, Y.T., 1999. Taxonomy and palaeoceanographical significance of the genus Krithe (Ostracoda) in the Brazilian margin. Journal of Micropaleontology, 18(2):111-123. https://doi.org/10.1144/jm.18.2.111

Ducasse, O., and Peypouquet, J.P., 1979. Cenozoic ostracodes: their importance for bathymetry, hydrology, and biogeography. In Montadert, L., and Roberts, D.G. (Eds.), Initial Report of the Deep Sea Drilling Project, 48: Washington, DC (U.S. Government Printing Office), 343-363. https://doi.org/10.2973/dsdp.proc.48.112.1979

Fanget, A.-S., Bassetti, M.A., Berne, S., and Arnaud, M., 2013. Epi-bathyal ostracod assemblage in Holocene Rhone deltaic sediments (Gulf of Lions, NW Mediterranean) and their palaeoecological implications. Revue de Paléobiologie, 32(2):589-606.

Guernet, C., 1985. Ostracodes paléogènes de quelques sites "D.S.D.P." de l'Océan Indien (Legs 22 et 23). Revue de Paléobiologie, 4:279-295.

Guernet, C., and Bellier, J.-P., 2000. Blake Nose Palaeogene and Eocene ostracods (Leg ODP 171B) and bathyal environmental evolution off Florida. Revue de Micropaléontologie, 43(4):249-279.

http://dx.doi.org/10.1016/S0035-1598(00)90140-5

Haskins, C.W., 1963. Revision of the ostracode genus Trachyleberidea Bowen. Micropaleontology, 9(1):71-74. https://doi.org/10.2307/1484608

Hazel, J.E., 1967. Corrections: classification and distribution of the Recent Hemicytheridae and Trachyleberididae (Ostracoda) off northeastern North America. Journal of Paleontology, 41(5):1284-1285.

Horne, D.J., Cohen, A., and Martens, K., 2002. Taxonomy, morphology and biology of Quaternary and living Ostracoda. In Holmes, J.A. and Chivas, A.R. (Eds.), The Ostracoda: Applications in Quaternary Research. Geophysical Monograph, 131:5-36.

https://doi.org/10.1029/131GM02

Hunt, G., 2007. Morphology, ontogeny, and phylogenetics of the genus Poseidonamicus (Ostracoda: Thaerocytherinae). Journal of Paleontology, 81(4):607-631. https://doi.org/10.1666/pleo00223360(2007)081[0607:MOAPOT]2.0.CO;2

Irizuki, T., Kusumoto, M., Ishida, K., and Tanaka, Y., 2007. Sea-level changes and water structures between 3.5 and $2.8 \mathrm{Ma}$ in the central part of the Japan Sea borderland: analyses of fossil Ostracoda from the Pliocene Kuwae Formation, central Japan. Palaeogeography, Palaeoclimatology, Palaeoecology, 245(3-4):421-443.

https://doi.org/10.1016/j.palaeo.2006.09.007

Ishii, T., Kamiya, T., and Tsukagoshi, A., 2005. Phylogeny and evolution of Loxoconcha (Ostracoda, Crustacea) spe- cies around Japan. Hydrobiologia, 538(1-3):81-94. https://doi.org/10.1007/s10750-004-4939-3

Jones, T.R., 1901. On some carboniferous shale from Siberia. Geological Magazine, 8(10):433-436. https://doi.org/10.1017/S0016756800179749

Katz, M.E., Cramer, B.S., Toggweiler, J.R., Esmay, G., Liu, C., Miller, K.G., Rosenthal, Y., Wade, B.S., and Wright, J.D., 2011. Impact of Antarctic Circumpolar Current development on late Paleogene ocean structure. Science, 332(6033):1076-1079. https://doi.org/10.1126/science.1202122

Maddocks, R.F., 1991. Revision of the family Pontocyprididae (Ostracoda), with new anchialine species and genera from Galapagos Islands. Zoological Journal of the Linnean Society of London, 103(4):309-333. https://doi.org/10.1111/j.1096-3642.1991.tb00907.x

Majoran, S., and Dingle, R.V., 2001. Cenozoic deep-sea ostracods from southwestern South Atlantic (DSDP/ ODP Site 329, 513, and 699). Revista Española de Micropaleontologia, 33:205-215.

Majoran, S., and Dingle, R.V., 2002. Cenozoic deep-sea ostracods from Maud Rise, Weddell Sea, Antarctica (ODP Site 689): a palaeoceanographical perspective. Geobios, 35(1):137-152.

https://doi.org/10.1016/S0016-6995(02)00016-5

Majoran, S., Kucera, M., and Widmark, J.G.V., 1998. Maastrichtian deep-sea ostracods from DSDP/ODP Site 327, 356, 527, 528, 529 and 698 in the South Atlantic. Revista Española de Micropaleontologia, 30(3):59-73.

Majoran, S., and Widmark, J.G.V., 1998. Response of deepsea ostracod assemblages to Late Cretaceous palaeoceanographical changes: ODP Site 689 in the Southern Ocean. Cretaceous Research, 19(6):843-872. https://doi.org/10.1006/cres.1998.0131

Martini, E., 1971. Standard Tertiary and Quaternary calcareous nannoplankton zonation. In Farinacci, A. (Ed.), Proceeding of the Second Planktonic Conference Roma 1970: Rome (Edizioni Tecnoscienza), 2:739-785.

McKenzie, K.G., Reyment, R.A., and Reyment, E.R., 1991. Eocene-Oligocene Ostracoda from South Australia and Victoria, Australia. Revista Española de Micropaleontologia, 6:135-175.

Müller, G.W., 1894. Fauna und flora des golfes von Neapel (Volume 21): Die ostracoden des golfes von Neapel und der angrenzenden meeres-abschnitte: Berlin (Verlag). https://doi.org/10.5962/bhl.title.7419

Neale, J.W., 1974. On Pennyella pennyi gen. et sp. nov. Stereo-Atlas of Ostracod Shells, 2:125-132.

Norris, R.D., Wilson, P.A., Blum, P., Fehr, A., Agnini, C., Bornemann, A., Boulila, S., Bown, P.R., Cournede, C., Friedrich, O., Ghosh, A.K., Hollis, C.J., Hull, P.M., Jo, K., Junium, C.K., Kaneko, M., Liebrand, D., Lippert, P.C., Liu, Z., Matsui, H., Moriya, K., Nishi, H., Opdyke, B.N., Penman, D., Romans, B., Scher, H.D., Sexton, P., Takagi, H., Turner, S.K., Whiteside, J.H., Yamaguchi, T., and Yamamoto, Y., 2014. Site U1411. In Norris, R.D., Wilson, P.A., Blum, P., and the Expedition 342 Scientists, Proceedings of the Integrated Ocean Drilling Program, 342: College Station, TX (Integrated Ocean Drilling Pro- 
gram).

http://dx.doi.org/10.2204/iodp.proc.342.112.2014

Osorio, R.O., 1978. Ostracoda from the Navidad Formation (Miocene), Chile. Journal of the Faculty of Science, Hokkaido University. Series 4, Geology and Mineralogy, 18(12):57-84. http://hdl.handle.net/2115/34824

Pascual, A., Rodriguez-Lazaro, J., Martín-Rubio, M., Jouanneau, J.-M., and Weber, O., 2009. A survey of the benthic microfauna (foraminifera, Ostracoda) on the Basque shelf, southern Bay of Biscay. Journal of Marine Systems, 72(1-4):35-63.

https://doi.org/10.1016/j.jmarsys.2007.05.015

Puri, H.S., 1954. Contribution to the study of the Miocene of the Florida Panhandle. Part 3: Ostracoda. Florida, Geological Survey, Geological Bulletin, 36:215-345.

Reuss, A.E., 1850. Die fossilen Entomostraceen des oesterreichischen Tertiaerbeckens. Naturwissenschftliche Abhandlungen, 3:41-92.

Rodriguez-Lázaro, J., and Cronin, T.M., 1999. Quaternary glacial and deglacial Ostracoda in the thermocline of the Little Bahama Bank (NW Atlantic): palaeoceanographic implications. Palaeogeography, Palaeoclimatology, Palaeoecology, 152(3-4):339-364. http://dx.doi.org/10.1016/S0031-0182(99)00048-6

Rodriguez-Lazaro, J., and Garcia-Zaraga, E., 1996. Paleogene deep-marine ostracodes from the Basque Basin. In Keen, M. (Ed.), Proceedings of the 2nd European Ostracodologists Meeting, Glasgow 1993, 79-86.

Ruan, P., and Hao, Y., 1988. Systematic description of microfossils. 2. Ostracoda. In Rong, L., and Shu, Z. (Eds.), Quaternary Microbiotas in the Okinawa Trough and their Geological Significance: Beijing (Geological Publishing House), 227-395.

Sars, G.O., 1866. Oversigt af Norges marine Ostracoder. Forhandlinger $i$ Videnskabsselskabet i Kristiania, 1865(1):1-130. (in Norwegian)

Sars, G.O., 1928. An Account of the Crustacea of Norway with Short Description and Figures of all the Species (Volume 9): Copenhagen, Denmark (Alb. Cammermeyers Forlag). https://doi.org/10.5962/bhl.title.1164

Steineck, P.L., Breen, M., Nevins, N., and O'Hara, P., 1984. Middle Eocene and Oligocene deep-sea Ostracoda from the Oceanic Formation, Barbados. Journal of Paleontology, 58(6):1463-1496.

http://www.jstor.org/stable/1304894

Steineck, P.L., Dehler, D., Hoose, E.M., and McCalla, D., 1988. Oligocene to Quaternary ostracods of the central equatorial Pacific (Leg 85, DSDP-IPOD). In Hanai, T., Ikeya, N., and Ishizaki, K. (Eds.), Developments in Palaeontology and Stratigraphy (Volume 11): Evolutionary Biology of Ostracoda: Tokyo/Amsterdam (Kodansha/ Elsevier), 597-617. https://doi.org/10.1016/S0920-5446(08)70210-3

Sylvester-Bradley, P.C., 1948. The ostracod genus Cythereis. Journal of Paleontology, 22(6):792-797. http://www.jstor.org/stable/1299620

Sylvester-Bradley, P.C., and Benson, R.H., 1971. Terminology for surface features in ornate ostracodes. Lethaia, 4(3):249-286.

https://doi.org/10.1111/j.1502-3931.1971.tb01924.x van den Bold, W.A., 1946. Contribution to the study of Ostracoda with special reference to the Tertiary and Cretaceous microfauna of the Caribbean region [Ph.D. thesis]. Utrecht University, Amsterdam.

van den Bold, W.A., 1958. Ostracoda of the Brasso Formation of Trinidad. Micropaleontology, 4(4):391-418. http://dx.doi.org/10.2307/1484268

van den Bold, W.A., 1960. Eocene and Oligocene Ostracoda of Trinidad. Micropaleontology, 6(2):145-196. https://doi.org/10.2307/1484466

van den Bold, W.A., 1969. Messinella, a new genus of Ostracoda in the Caribbean Cenozoic. Micropaleontology, 15(4):397-400. https://doi.org/10.2307/1484890

Via, R.K., and Thomas, D.J., 2006. Evolution of Atlantic thermohaline circulation: early Oligocene onset of deep-water production in the North Atlantic. Geology, 34(6):441-444. http://dx.doi.org/10.1130/G22545.1

Wade, B.S., Pearson, P.N., Berggren, W.A., and Pälike, H., 2011. Review and revision of Cenozoic tropical planktonic foraminiferal biostratigraphy and calibration to the geomagnetic polarity and astronomical time scale. Earth-Science Reviews, 104(1-3):111-142. https://doi.org/10.1016/j.earscirev.2010.09.003

Whatley, R., and Coles, G., 1987. The late Miocene to Quaternary Ostracoda of Leg 94, Deep Sea Drilling Project. Revista Espanola de Micropaleontologia, 19:33-97.

Whatley, R., and Zhao, Q., 1993. The Krithe problem: a case history of the distribution of Krithe and Parakrithe (Crustacea, Ostracoda) in the South China Sea. Palaeogeography, Palaeoclimatology, Palaeoecology, 103(3-4):281-297. https://doi.org/10.1016/0031-0182(93)90146-A

Whatley, R.C., and Coles, G.P., 1991. Global change and the biostratigraphy of North Atlantic Cainozoic deep water Ostracoda. Journal of Micropaleontology, 9:119-132. https://doi.org/10.1144/jm.9.2.119

Yamaguchi, T., Bornemann, A., Matsui, H., and Nishi, H., 2017a. Latest Cretaceous/Paleocene deep-sea ostracode fauna at IODP Site U1407 (western North Atlantic) with special reference to the Cretaceous/Paleogene boundary and the Latest Danian Event. Marine Micropaleontology, 135:32-44.

https://doi.org/10.1016/j.marmicro.2017.07.003

Yamaguchi, T., Matsui, H., and Nishi, H., 2017b. Taxonomy of Maastrichtian-Thanetian deep-sea ostracodes from U1407, IODP Exp 342, off Newfoundland, Northwestern Atlantic, part 1: Families Cytherellidae, Bairdiidae, Pontocyprididae, Bythocytheridae, and Cytheruridae. Paleontological Research, 21(1):54-75. http://dx.doi.org/10.2517/2016PR010

Yamaguchi, T., Matsui, H., and Nishi, H., 2017c. Taxonomy of Maastrichtian-Thanetian deep-sea ostracodes from U1407, IODP Exp 342, off Newfoundland, Northwestern Atlantic, part 2: Families Eucytheridae, Krithidae, Thaerocytheridae, Trachyleberididae, and Xestoleberididae. Paleontological Research, 21(2):97-121. https://doi.org/10.2517/2016PR011

Yamaguchi, T., and Norris, R.D., 2012. Deep-sea ostracode turnovers through the Paleocene-Eocene Thermal Maximum in DSDP Site 401, Bay of Biscay, North Atlantic. 
Marine Micropaleontology, 86-87:32-44.

https://doi.org/10.1016/j.marmicro.2012.02.003

Yamaguchi, T., Norris, R.D., and Bornemann, A., 2012.

Dwarfing of ostracodes during the Paleocene-Eocene

Thermal Maximum at DSDP Site 401 (Bay of Biscay,

North Atlantic) and its implication for changes in

organic carbon cycle in deep-sea benthic ecosystem.

Palaeogeography, Palaeoclimatology, Palaeoecology, 346347:130-144.

https://doi.org/10.1016/j.palaeo.2012.06.004

Yasuhara, M., Hunt, G., Okahashi, H., and Brandão, S.N., 2013. The 'Oxycythereis' problem: taxonomy and palaeobiogeography of deep-sea ostracod genera Pennyella and Rugocythereis. Palaeontology, 56(5):1045-1080.

http://dx.doi.org/10.1111/pala.12035
Yasuhara, M., Hunt, G., Okahashi, H., and Brandão, S.N., 2015. Taxonomy of deep-sea Trachyleberidid, Thaerocytherid, and Hemicythrid genera (Ostracoda). Smithsonian Contributions to Paleobiology, 96.

https://doi.org/10.5479/si.1943-6688.96

Zhao, Q., and Whatley, R., 1997. Distribution of the ostracod genera Krithe and Parakrithe in bottom sediments of the East China and Yellow Seas. Marine Micropaleontology, 32(1-2):195-207.

https://doi.org/10.1016/S0377-8398(97)00020-0

Initial receipt: 10 February 2017

Acceptance: 7 November 2017

Publication: 2 March 2018

MS 342-206 
Figure F1. Location of Site U1411 and other ocean drilling sites discussed.

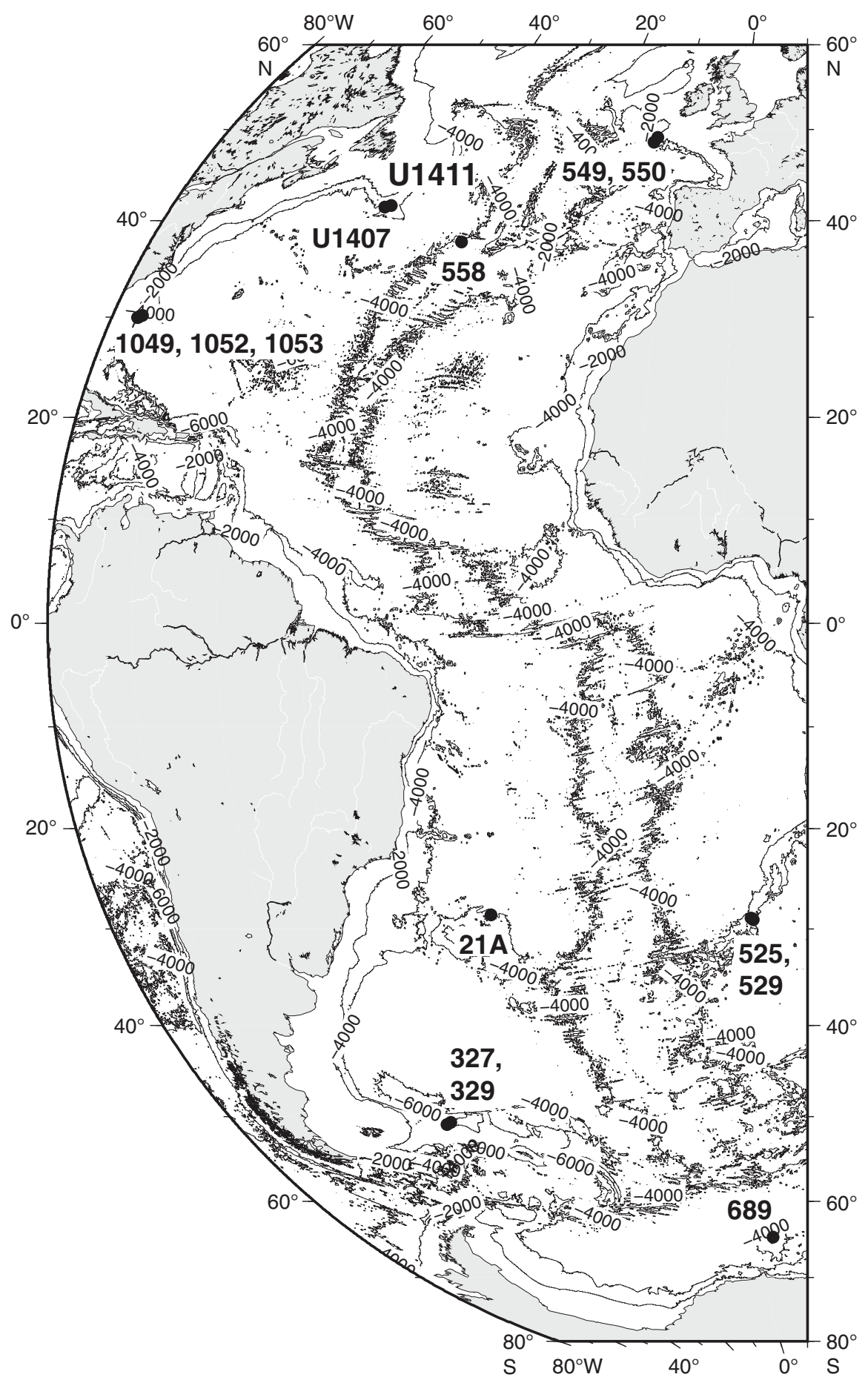


Figure F2. Tracing of specimens in Plate P6. AD = antero-dorsal radial pore canal (designed by Coles et al. [1994]). Scale bars $=100 \mu \mathrm{m}$. A. Argilloecia sp., Specimen MPC-15259, adult left valve. B, C. Krithe crassicaudata van den Bold; (B) Specimen MPC-15266, adult left valve; (C) Specimen MPC-15265, juvenile left valve. D. Krithe dolichodeira van den Bold, Specimen SIO-BIC-C12210, adult right valve. E. Krithe pernoides pernoides (Bornemann), Specimen MPC-15269, adult left valve. F. Krithe trinidadensis van den Bold, Specimen MPC-15271, adult right valve. G. Parakrithe vermunti (van den Bold), Specimen MPC-15272, adult left valve.
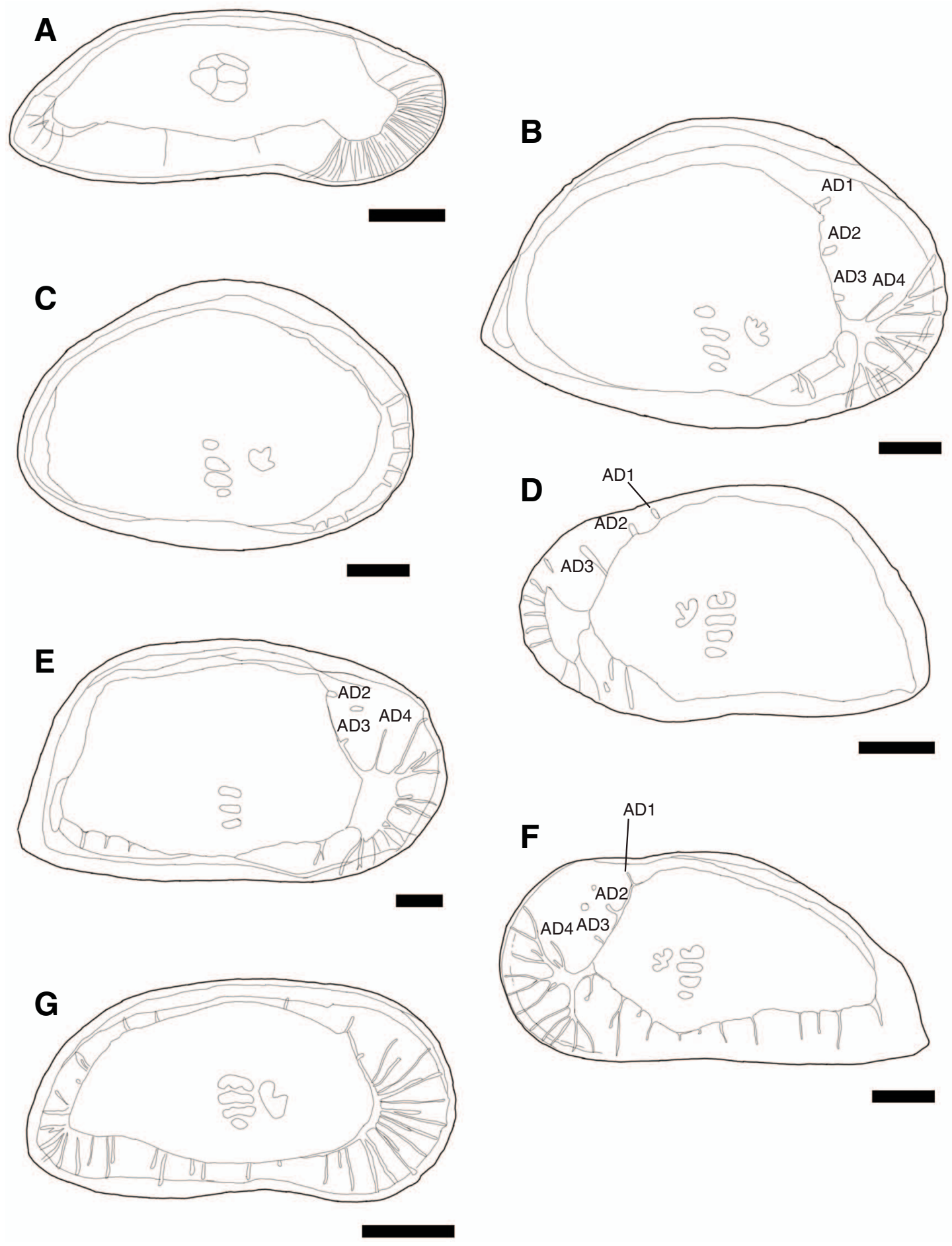
Figure F3. Plot of Krithe crassicaudata and Messinella valve length vs. height. Detailed K. crassicaudata measurements are shown in Table T2. Messinella measurements are from van den Bold (1969). LV = left valve, RV = right valve.

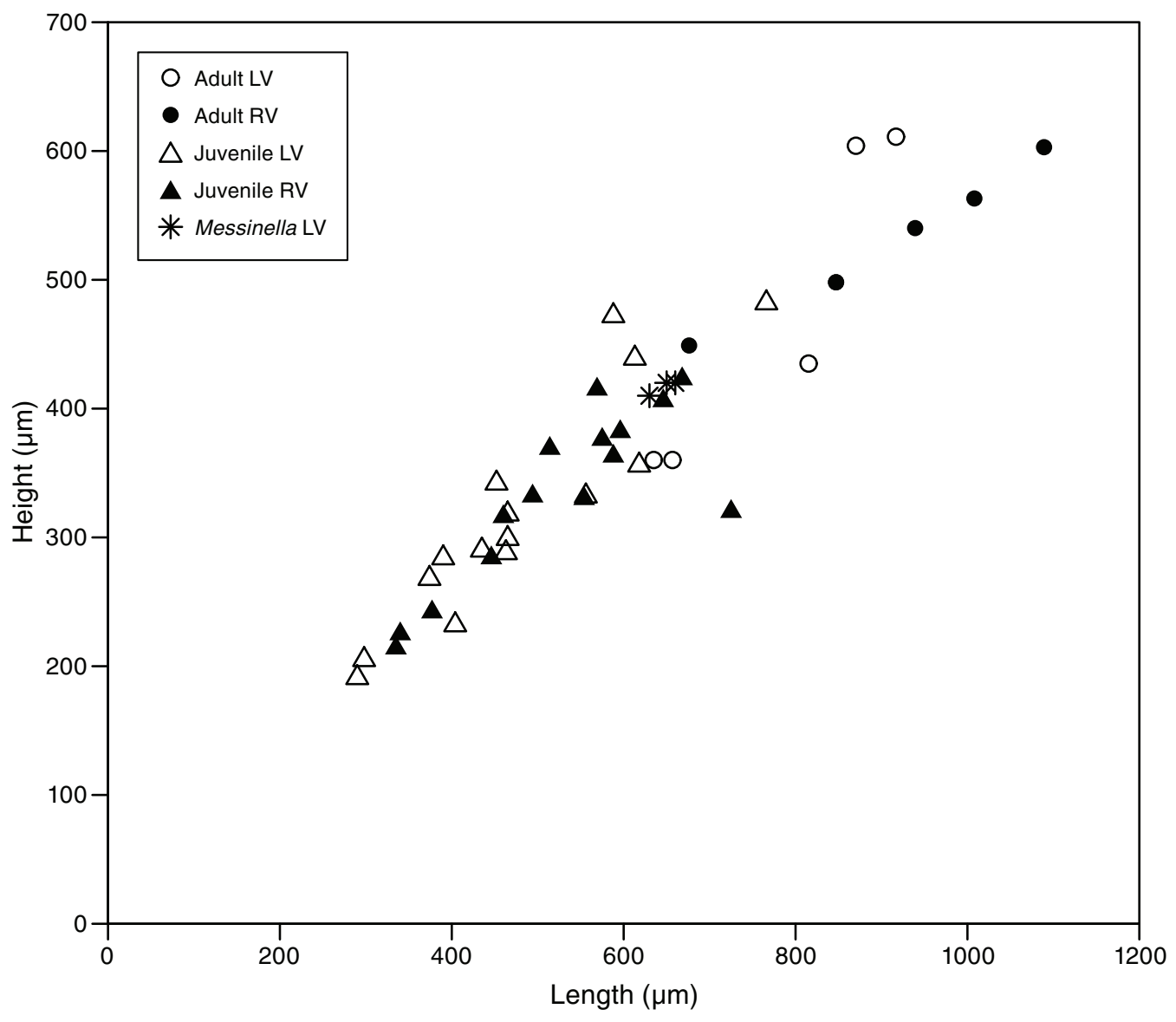


Table T1. Specimen measurements and features, Hole U1411B. This file is available in CSV format.

Table T2. Krithe crassicaudata measurements, Hole U1411B. This file is available in CSV format.

Table T3. Ostracod taxa counts from Hole U1411B sediments. This file is available in CSV format. 
Plate P1. Scanning electron microscope (SEM) images. Scale bars $=100 \mu \mathrm{m} .1$, 2. Cytherella sp. (1: Specimen MPC-15258, adult left valve, external view; 2: Specimen SIO-BIC-C12204, adult right valve, external view). 3, 4. Bairdoppilata sp. Specimen MPC-15282, juvenile left valve (3: external view, 4: internal view). 5, 6. Bythocypris sp. Specimen MPC-15281, adult left valve (5: external view, 6: internal view). 7, 8. Argilloecia sp., Specimen MPC-15259, adult left valve (7: external view, 8: internal view). 9, 10. Bythocytheridae gen. et sp. indet., Specimen MPC-15260, adult right valve (9: external view, 10: internal view).

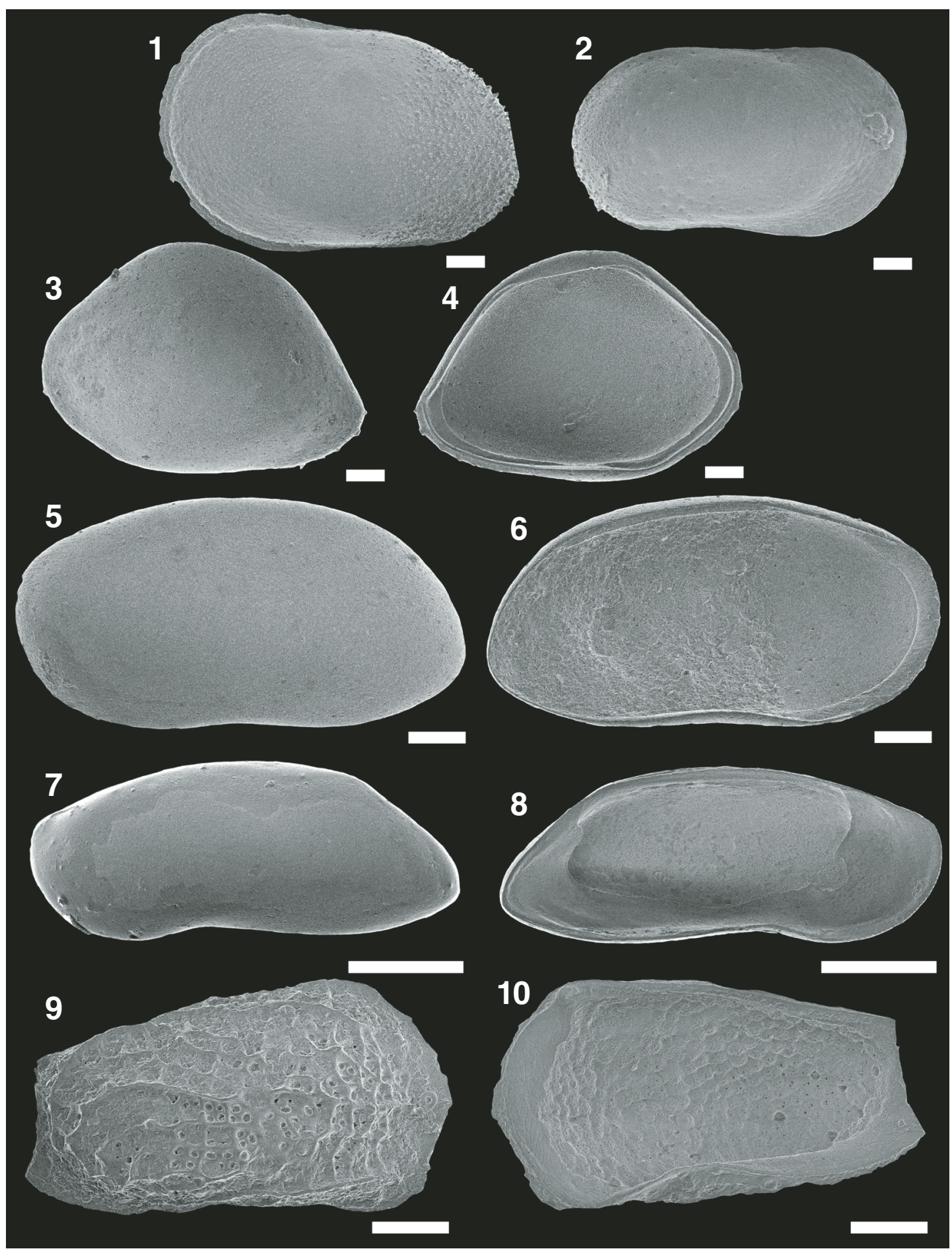


Plate P2. SEM images. Scale bars $=100 \mu \mathrm{m}$. Arrows $=$ anterior direction. 1. Aversovalva formosa Coles and Whatley, Specimen MPC-15261, adult left valve (external view). 2. Cytheropteron americanum Yamaguchi, Matsui, and Nishi, Specimen MPC-15262, adult right valve (external view). 3. Pelecocythere sp., Specimen MPC15263, adult right valve (external view). 4. Eucythere sp., Specimen MPC-15264, adult right valve (external view). 5-8. Krithe crassicaudata van den Bold; $(5,6)$ Specimen MPC-15266, adult left valve (5: external view, 6: dorsal view); $(7,8)$ Specimen MPC-15265. juvenile left valve (7: external view, 8: dorsal view).

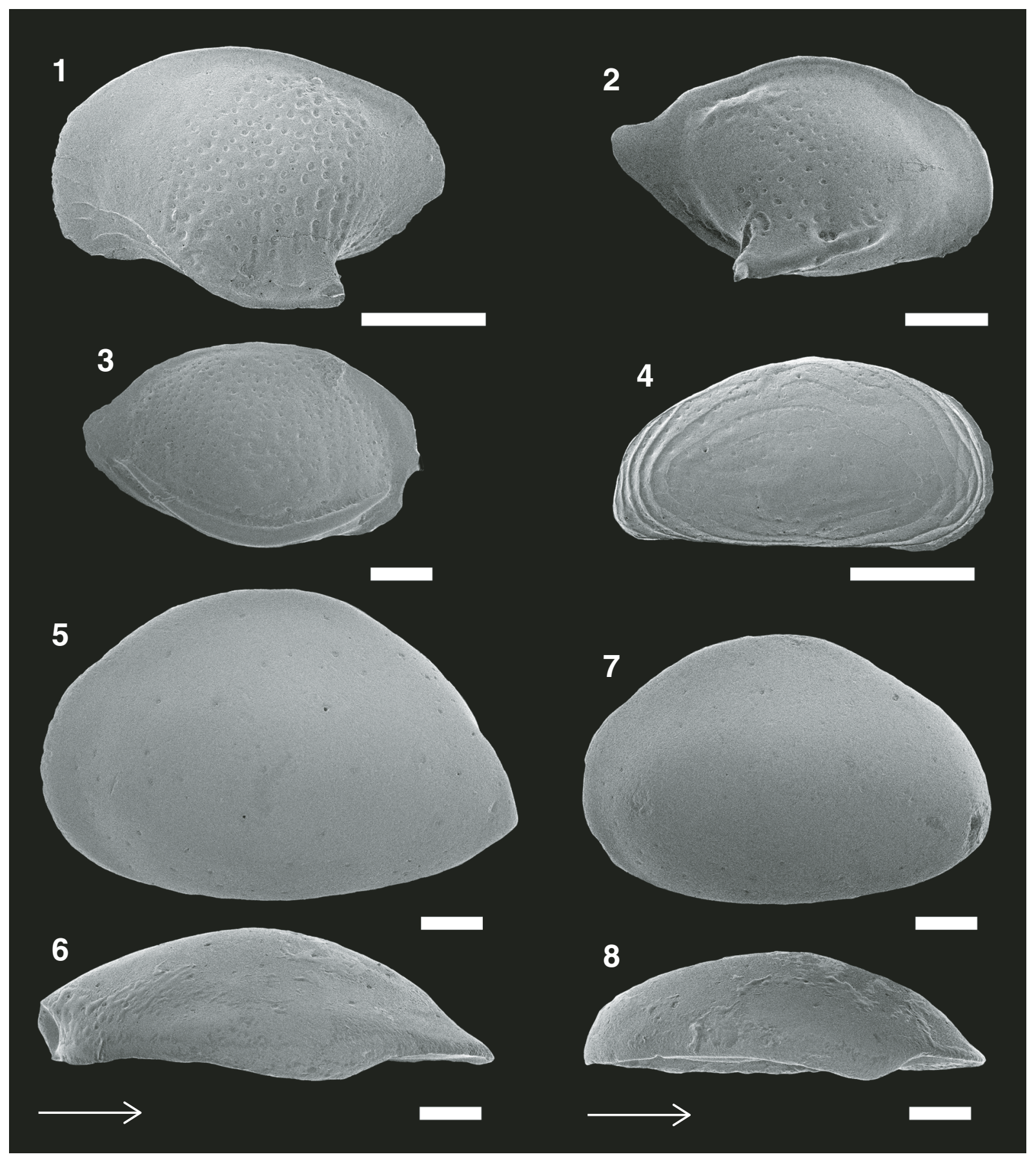


Plate P3. SEM images. Scale bars $=100 \mu \mathrm{m} .1-4$. Krithe crassicaudata van den Bold; $(1,2)$ Specimen MPC-15266, adult left valve (1: internal view, 2: hingement); $(3,4)$ Specimen MPC-15265, juvenile left valve (3: internal view, 4: hingement). 5, 6. Krithe dolichodeira van den Bold, Specimen SIO-BIC-C12210, adult right valve (5: external view, 6: internal view). 7, 8. Krithe pernoides pernoides (Bornemann), Specimen MPC-15269, adult left valve (7: external view, 8: internal view). 9, 10. Krithe trinidadensis van den Bold, Specimen MPC-15271, adult right valve (9: external view, 10: internal view).

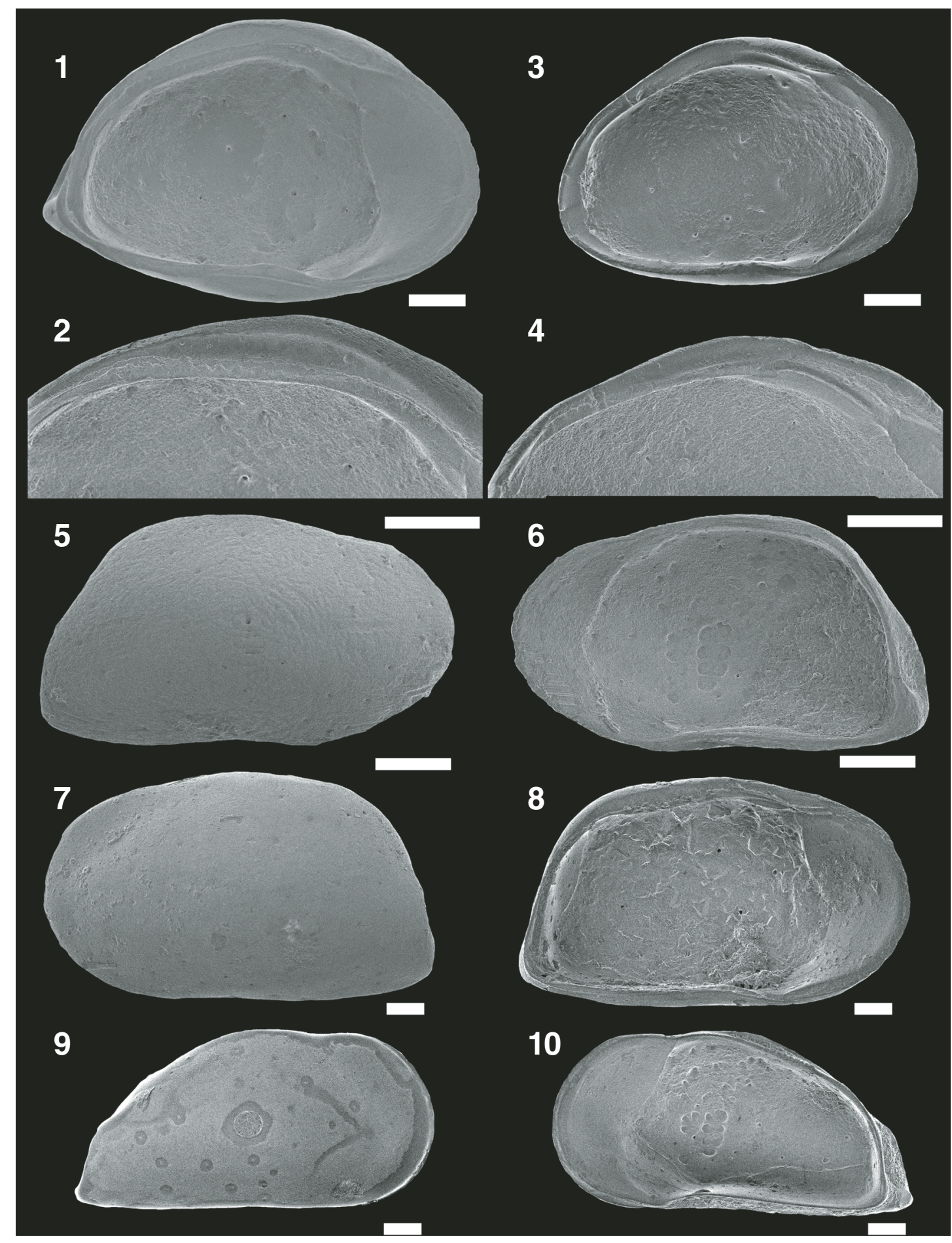


Plate P4. SEM images. Scale bars $=100 \mu \mathrm{m} .1$, 2. Parakrithe vermunti (van den Bold), Specimen MPC-15272, adult left valve (1: external view, 2: internal view). 3, 4. Loxoconcha sp., Specimen MPC-15273, adult right valve (3: external view, 4: internal view). 5. Paracytheridea sp., Specimen MPC-15274, adult left valve (external view). 6. Croninocythereis tridentiferae Yasuhara, Hunt, Okahashi, and Brandão, Specimen MPC-15276, adult right valve (external view). 7. Poseidonamicus pseudorobustus Coles and Whatley, Specimen SIO-BIC-C12216, adult right valve (external view).

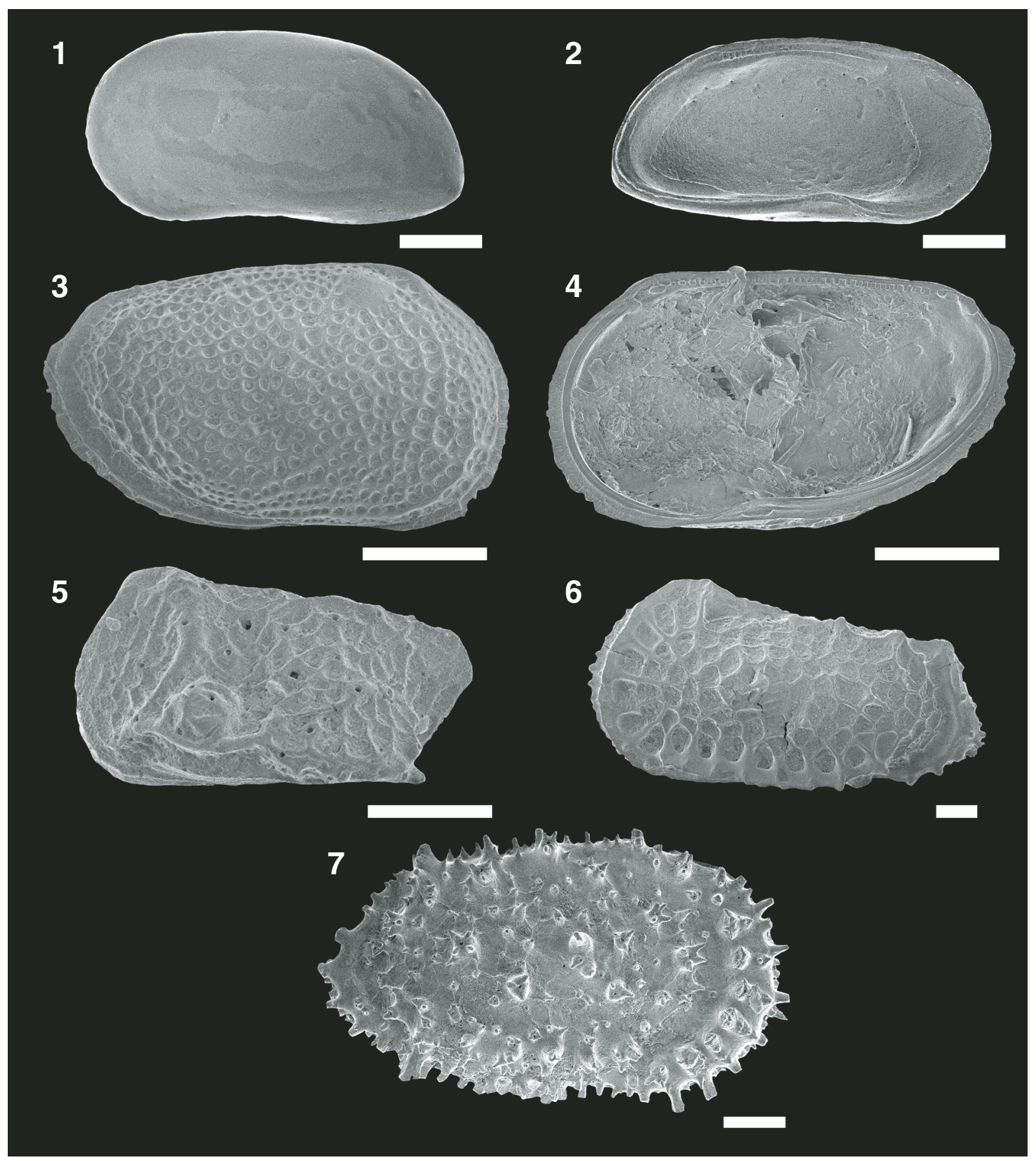


Plate P5. SEM images. Scale bars $=100 \mu \mathrm{m}$. Arrow $=$ anterior direction. 1. Dutoitella mimica Dingle, Specimen MPC-15278, adult right valve (external view). 2. Henryhowella asperrima (Reuss), Specimen SIO-BIC-C12216, adult right valve (external view). 3-6. Pennyella sp., Specimen MPC-15277, adult right valve (3: external view, 4: internal view, 5: hingement, 6: muscle scars). 7, 8. Trachyleberidea sp., Specimen MPC-15283, juvenile left valve (7: external view, 8: internal view). 9. Platyleberis sp., Specimen MPC-15280, adult right valve (external view).

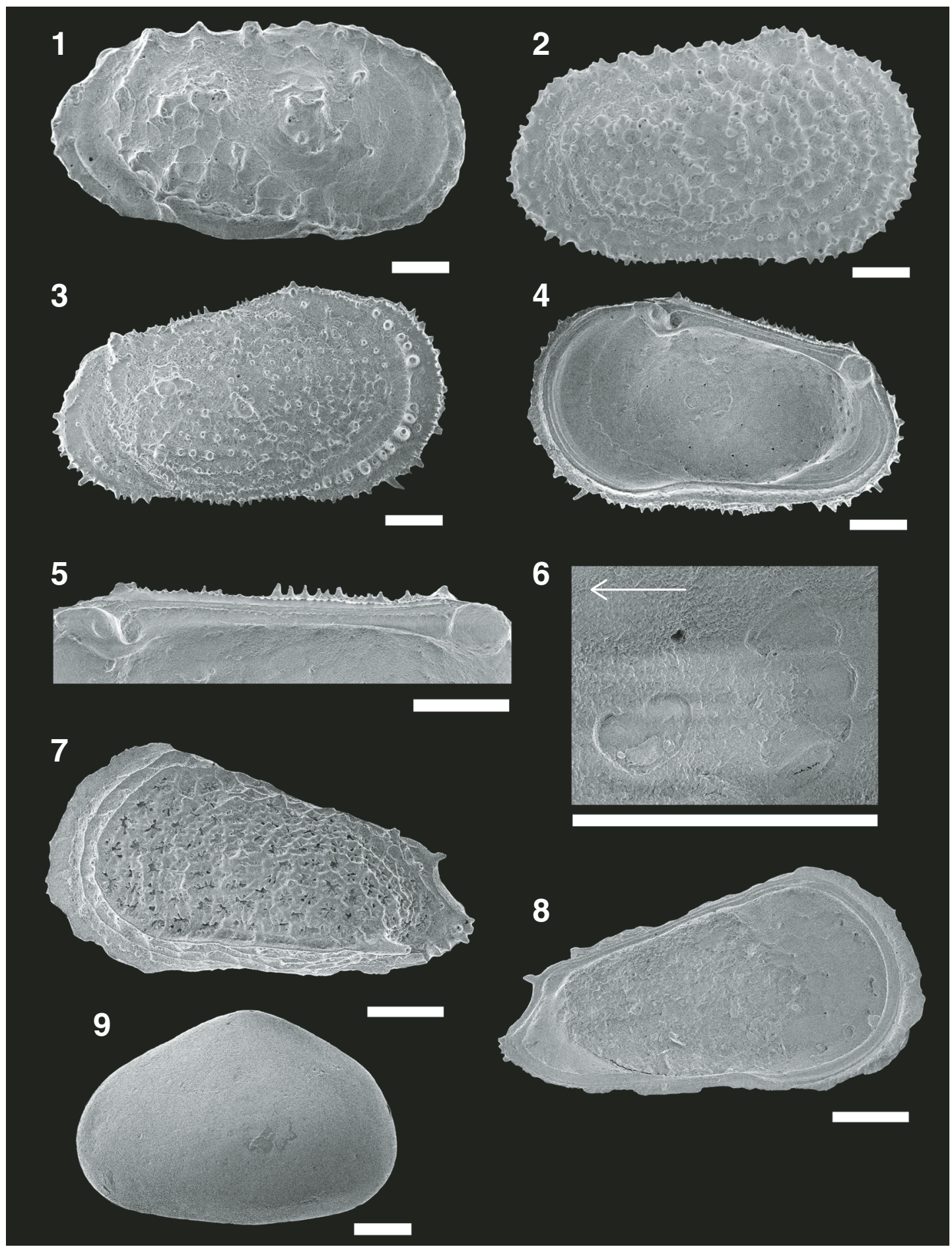


Plate P6. Transmitted light optical microscope images of internal structures of specimens. All the images were captured. Scale bars $=100 \mu \mathrm{m}$. 1. Argilloecia sp., Specimen MPC-15259, adult left valve. 2, 3. Krithe crassicaudata van den Bold; (2) Specimen MPC-15266, adult left valve; (3) Specimen MPC-15265, juvenile left valve. 4. Krithe dolichodeira van den Bold, Specimen SIO-BIC-C12210, adult right valve. 5. Krithe pernoides pernoides (Bornemann), Specimen MPC-15269, adult left valve. 6. Krithe trinidadensis van den Bold, Specimen MPC-15271, adult right valve. 7. Parakrithe vermunti (van den Bold), Specimen MPC-15272, adult left valve.
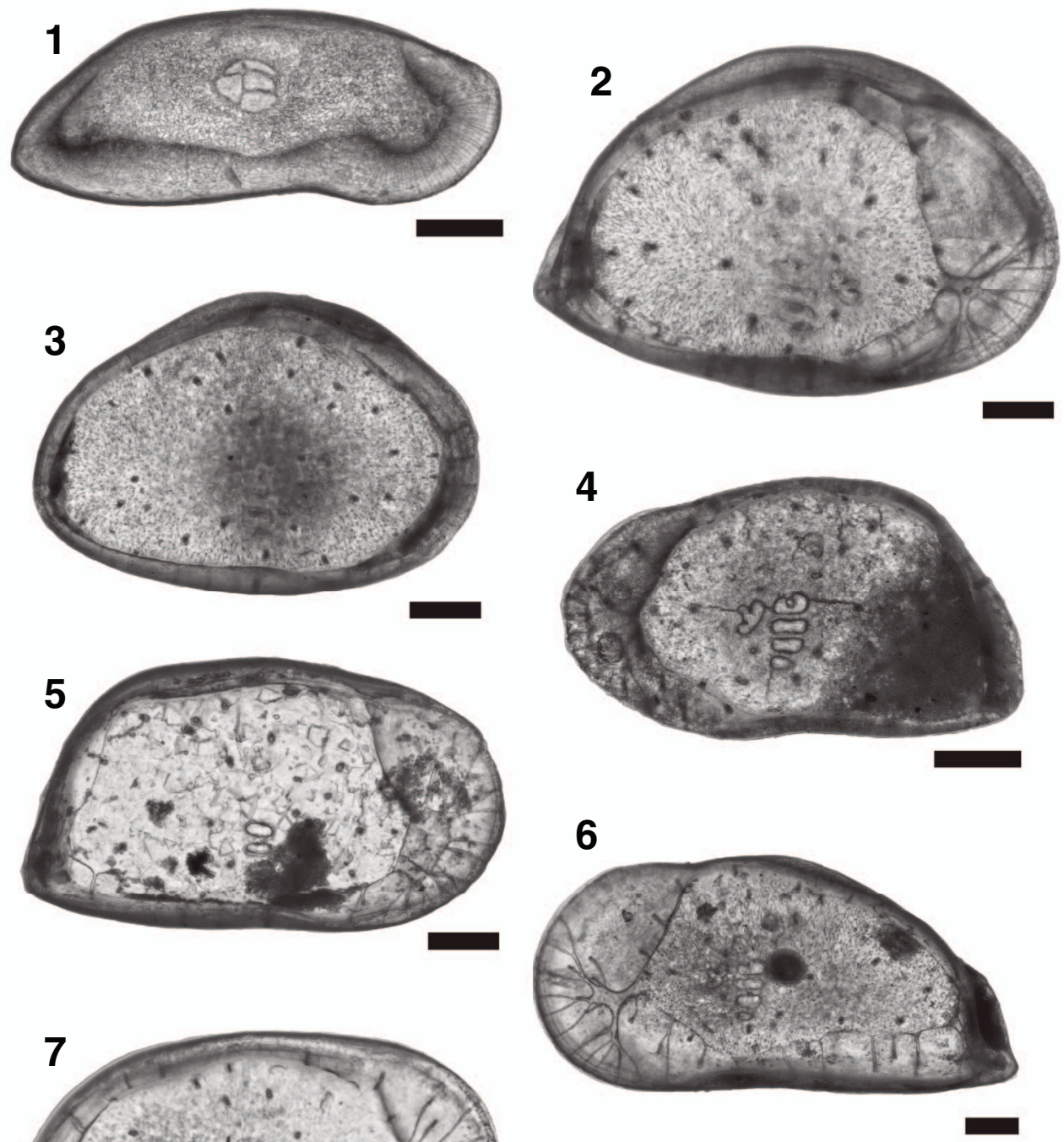


\section{Appendix}

Systematic paleontology of selected taxa

\author{
Suborder CYPRIDOCOPINA Jones, 1901 \\ Superfamily PONTOCYPRIDOIDEA Müller, 1894 \\ Family PONTOCYPRIDIDAE Müller, 1894 \\ Genus ARGILLOECIA Sars, 1866; emend. Maddocks, \\ 1991
}

\section{Argilloecia sp.}

(Fig. F2A; P1. P1, figs. 7, 8; Pl. P6, fig. 1)

Description: Adult carapace robust and medium (591$598 \mu \mathrm{m}$ long). In external view, lateral outline elongated subtrapezoidal: anterior margin round; posterior margin tapering; dorsal margin gentle arched; ventral margin curved, concave up in the anterior. Surface smooth. In internal view, anterior and ventral marginal zones are well developed. Anterior marginal pore canals: 46 straight or straightly curved. Adductor muscle scars round, formed by five scars: in anterior row, three elliptical scars; in posterior row, two subtriangle scars.

Remarks: In the lateral outline, this species is similar to Argilloecia sp. of Yamaguchi et al. (2017b) that was reported from upper Paleocene sediments at Site U1407. However it is different from the Paleocene species in having five adductor muscle scars.

\section{Suborder CYTHEROCOPINA Baird, 1850 Superfamily CYTHEROIDEA Baird, $\mathbf{1 8 5 0}$ Family BYTHOCYTHERIDAE Sars, 1866}

Gen. et sp. indet.

(Pl. P1, figs. 9, 10)

Description: Adult carapace thin and small $(384 \mu \mathrm{m}$ long). In external view, lateral outline subrectangular: anterior margin angular with apex near middle; dorsal and posterior margins slightly sinuous. Maximum height across antero-dorsal corner. Surface ornamented with primary and secondary reticulations and spines. Primary reticulation formed by distinct horizontal muri and polygonal fossae. In secondary reticulation, fossae are round. Conjunctive and disjunctive spines on postero-central area. In internal view, lophodont-type hingement: round tooth of anterior element; smooth median groove. Anterior and postero-ventral marginal zones developed.

Remarks: Only two specimens were obtained from Sample 342-U1411B-26X-7W, 40-42 cm. The species is similar to Gen. et sp. 1 of Guernet and Bellier (2000) in the lateral outline and reticulated ornaments. Gen. et sp. 1 was reported from Maastrichtian sediments at ODP Site 1049, northwestern Atlantic. It is different from the Maastrichtian taxon in the direction of muri on the antero-ventral area. The Eocene species shows horizontal muri on the area, whereas the Maastrichtian taxon exhibits convexly curved muri.
Family EUCYTHERIDAE Puri, 1954
Genus EUCYTHERE Brady, 1868

Eucythere sp.

(Pl. P2, fig. 4)

Eucythere cf. circumcostata Whatley and Coles: Majoran and Widmark, 1998, p. 853, fig. 3.4; Majoran et al., 1998, p. 63, pl. 1, fig. 14; Majoran and Dingle, 2002, p. 148, fig. 3.5.

Eucythere sp. Bergue and Nicolaidis, 2012, p. 52, fig. 2.22.

Description: Adult carapace robust and small (385 $\mu \mathrm{m}$ long). Lateral outline ovate: anterior margin round; posterior margin round with apex at lower one-third of the margin; dorsal margin slightly arched; ventral margin curved with concave up near middle. Postero-dorsal corner angular. Posterior cardinal angle obtuse. Maximum length across middle of anterior margin; maximum height across antero-dorsal corner. Surface with five concentric carinae and punctae: first and second carinae distinct on anterior and posterior areas; third carina distinct on postero-central area. Punctae distributed along concentric carinae.

Stratigraphic distribution: Maastrichtian-Chattian. The species occurs from Maastrichtian sediments at DSDP Site 525 (Majoran et al., 1998), southeastern Atlantic, and ODP Site 689 (Majoran and Widmark, 1998), Southern Ocean, and from Danian-Chattian sediments at Site 689 (Majoran and Dingle, 2002). It is reported from the Oligocene at DSDP Site 329, southwestern Atlantic (Bergue and Nicolaidis, 2012).

Remarks: As pointed out by Majoran and Dingle (2002), the species is different from the types of E. circumcostata Whatley and Coles, 1987, in lacking punctae on the central area.

\section{Family KRITHIDAE Mandelstam cited in Bubikyan, 1958}

Genus KRITHE Brady, Crosskey, and Robertson, 1874

Krithe crassicaudata van den Bold, 1946

(Fig. F2B-F2C; Pl. P2, figs. 5-8; Pl. P3, figs. 1-4; Pl. P6, figs. 2-3)

Krithe crassicaudata van den Bold, 1946, p. 78, pl. 7, fig. 2af; van den Bold, 1960, p. 158, pl. 3, fig. 7a-d; Yamaguchi and Norris, 2012, p. 36, figs. 3.11, 4.1; Yamaguchi et al., 2012, fig. 3.

Krithe sp. Cronin and Compton-Goodin, 1987, pl. 6, figs. 4,7 .

Description: Adult carapace robust and large in size (635-1089 $\mu \mathrm{m}$ long). Right valve (RV) dorsally overlapped by left valve (LV). In external view, lateral outline ovate: round anterior margin; angular posterior margin; arched dorsal margin; posterior margin concavely curved. Dorsal outline of LV half elliptical: anterior edge tapering; posterior edge angular with indent; outside margin round; dorsal contact to RV obviously curved near middle of valve. Smooth surface. In internal view, lophodont-type hingement: in LV, elongated socket of anterior element: smooth median bar; crenulated socket of posterior element. Broad 
anterior marginal zone with Y-shaped vestibulum and 13 anterior radial pore canals (ARPCs). ARPC straight or bifurcated. Antero-dorsal radial pore canals (AD): short AD1$\mathrm{AD} 3$ and elongated AD4. Four ovate adductor muscle scars arranged in a row. Frontal muscle scar trilobate.

Juvenile carapace robust and small to large in size (290$766 \mu \mathrm{m}$ long). RV slightly smaller than LV. In external view, lateral outline ovate: round anterior margin; angular posterior margin; arched dorsal margin; posterior margin concavely curved. Dorsal outline of LV half elliptical: anterior edge tapering; posterior edge round; outside margin round; dorsal contact to RV obviously curved near middle of valve. Smooth surface. In internal view, lophodont-type hingement: in LV, elongated socket of anterior element; smooth median bar; half-round socket with crenulation of posterior element. Anterior marginal zone narrow. Eight straight ARPCs. Adductor and frontal muscle scars as same as adult form.

Stratigraphic distribution: Maastrichtian-Aquitanian. Coles et al. (1994) indicated that this species ranges from calcareous nannofossil Zones NP18 to NN1 of Martini (1971). Yamaguchi et al. (2017a) reported the species from the Maastrichtian at Site U1407.

Remarks: Coles et al. (1994) considered Messinella van den Bold, 1969, as a junior synonym of Krithe crassicaudata. Messinella was originally described from the Neogene Manchioneal Formation in Jamaica. The juvenile form of the species is as large as Messinella species (Table T2; Fig. F3) and similar to Messinella species in the ovate lateral outline with the maximum height across the middle of the valve and straight-shaped ARPC. However, the juvenile form of K. crassicaudata is distinguished from Messinella species by having a trilobate frontal muscle scar and the elongated anterior element without crenulation in the hingement in the internal view, and a curved dorsal contact of LV to RV in the dorsal view. The genus Messinella shows one or two elongate frontal muscle scars and the lophodont-type hingement with crenulated anterior and posterior elements in the internal view and a slightly curved dorsal contact in the dorsal view (van den Bold, 1969).

Krithe dolichodeira van den Bold, 1946

(Fig. F2D; Pl. P3, figs. 5, 6; Pl. P6, fig. 4)

Krithe dolichodeira van den Bold, 1946, p. 75. pl. 4, fig. 14a, b; Coles et al., 1994, p. 81, pl. 1, figs. 13-18; Ayress et al., 1999, p. 6, fig. 3, G, H; Alvarez Zarikian, 2015, pl. 2, figs. 1-3.

Parakrithe hemideclivata Ruan in Ruan and Hao, 1988, p. 272, pl. 45, figs. 12-15.

Krithe hemideclivata (Ruan and Hao, 1988), Whatley and Zhao, 1993, figs. 3, 9; Zhao and Whatley, 1997, figs. 5, 4; Irizuki et al., 2007, figs. 5, 3.

Stratigraphic distribution: Maastrichtian-present. Coles et al. (1994) illustrated that the species has persisted since calcareous nannofossil Zone NP10 of Martini (1971) (55.81-54.17 Ma). Yamaguchi et al. (2017a) reported the species from the Maastrichtian at Site U1407.
Krithe pernoides pernoides (Bornemann, 1855)

(Fig. F2E; Pl. P3, figs. 7, 8; Pl. P6, fig. 5)

For comprehensive pre-1994 synonymy see Coles et al. (1994).

Krithe pernoides pernoides (Bornemann). Coles et al., 1994, p. 104, pl. 5, figs. 7-12, text-fig. 5K-Q.

Stratigraphic distribution: Lutetian-present. In the North Atlantic, Coles et al. (1994) states that the species appeared in calcareous nannofossil Zone NP15 of Martini (1971) (46.29-42.87 Ma) and persisted to Zone NN19 (1.93-0.44 Ma). This species is found in the Bay of Biscay (Pascual et al., 2009) and Holocene sediments in the Mediterranean (Fanget et al., 2013; Angue Minto'o et al., 2015).

\section{Krithe trinidadensis van den Bold, 1958}

(Fig. F2F; P1. P3, figs. 9, 10; Pl. P6, fig. 6)

For comprehensive pre-1999 synonymy see Do Carmo and Sanguinetti (1999).

Krithe trinidadensis van den Bold: Ayress et al., 1999, p. 16, figs. 2I, 2J, 7H-L, 8FF, 8GG; Do Carmo and Sanguinetti, 1999, p. 114, pl. 1, fig. 3; Rodriguez-Lazaro and Cronin, 1999, fig. 3.4, pl. 1.7-1.8; Bergue et al., 2006, fig. 7B; Bergue et al., 2013, p. 31, fig. 3M-3P; Alvarez Zarikian, 2009, pl. P7, fig. 5.

Stratigraphic distribution: Lutetian-present (Coles et al., 1994; Do Carmo and Sanguinetti, 1999). The species ranges from calcareous nannofossil Zone NP16 of Martini (1971) (42.87-40.40 Ma) to the present.

Remarks: The species shows variation in the lateral outline. The illustrated specimen is similar to the specimens of Ayress (1999, fig. 7H) and Bergue et al. (2013, fig. 3N, 3P) in an arched margin from the posterior half of the dorsal margin to the upper half of the posterior margin.

\section{Genus PARAKRITHE van den Bold, 1958}

\section{Parakrithe vermunti (van den Bold, 1946)}

(Fig. F2G; Pl. P4, figs. 1, 2; Pl. P6, fig. 7)

Cytheridea (Dolocytheridea) vermunti van den Bold, 1946, p. 83, pl. 7, fig. 12a-c.

Parakrithe vermunti (van den Bold). van den Bold, 1958, p. 399, pl. 4, fig. 7a-f; Osorio, 1978, p. 68, pl. 2., fig. 4.

Description: Adult carapace robust and small (434-487 $\mu \mathrm{m}$ long). In lateral view, subovate lateral outline: anterior margin round; posterior margin round with apex near ventral one-third; dorsal margin arched; ventral margin curved, convex up near anterior one-third. Smooth surface. In internal view, merodont-type hingement: in LV, shallow socket of anterior element; smooth median bar; crenulate socket with five teeth of posterior elements. Marginal zones well developed from anterior to posterior via ventral margin. Vestibulum very narrow. Pore canals: 20 anterior and 13 posterior slightly curved or bifurcated. Four ovate muscle scars arranged vertically in a row. Ushaped frontal muscle scar. 
Stratigraphic distribution: Priabonian-Messinian. This species was originally described from Oligocene and Miocene sediments in Cuba (van den Bold, 1946). It was reported from lower Oligocene-middle Miocene sediments in Trinidad (van den Bold, 1958). At Site U1411, it is found in upper Eocene and lower Oligocene sediments. In the Pacific, Steineck et al. (1988) assigned the stratigraphic range of the species as planktonic foraminifer Zones N.9-N.17 of Blow (1969), which is correlated with Zones M4 to lower PL1 of Wade et al. (2011). Osorio (1978) reported the species from the Miocene Navidad Formation in Chile.

Family LOXOCONCHIDAE Sars, 1928

Genus LOXOCONCHA Sars, 1928; emend. Athersuch and Horne, 1984

\section{Loxoconcha sp.}

(Pl. P4, figs. 3, 4)

Description: Juvenile carapace thin and small (385 $\mu \mathrm{m}$ long). In external view, lateral outline subrhomboidal: anterior margin round; posterior margin round with apex near dorsal one-fourth; dorsal margin slightly arched; ventral margin sinuous with concave up area near middle. Surface reticulated with round fossae. Eye tubercle prominent. In internal view, gongylodont-type hingement: in RV, two teeth and one socket of anterior element; median groove with teeth; two elongated teeth and one socket of posterior element.

Remarks: Only one specimen was found. Lacking the anterior and posterior marginal rims and having the gongylodont-type hingement with the crenulated median element indicate the genus Loxoconcha s.s. Athersuch and Horne (1984) redefined Loxoconcha s.s. and considered it to be restricted to the Neogene and Quaternary. Ishii et al. (2005) recognized Loxoconcha punctabella McKenzie, Reyment, and Reyment, 1991 from the upper Oligocene sediments in Australia as Loxoconcha s.s. and pointed out that the genus appeared during the late Paleogene. Loxoconcha sp. indicates that the genus s.s. appeared during the early Oligocene. This species is different from $L$. punctabella in having a smaller carapace with a slightly curved dorsal margin.

\section{Family THAEROCYTHERIDAE Hazel, 1967 Genus POSEIDONAMICUS Benson, 1972}

\section{Poseidonamicus pseudorobustus Coles and Whatley, 1989}

(Pl. P4, fig. 6)

Poseidonamicus pseudorobustus Coles and Whatley, 1989, p. 119, pl. 5, figs. 13-15; Coles, 1996, pl. 2, fig. 10; Hunt, 2007, fig. 8.4; Bergue and Nicolaidis, 2012, p. 54, fig. 3.20-3.21.

Stratigraphic distribution: Priabonian-Chattian. At Site U1411, the species is found in sediments from calcareous nannofossil Zone NP19-NP20 (36.97-34.44 Ma). Coles (1996) indicated the range of the species correlated with calcareous nannofossil Zone NP21-NP25 of Martini (1971) (34.44-23.13 Ma) in the North Atlantic. The species was reported from Oligocene sediments at Site 329 in the southwestern Atlantic (Bergue and Nicolaidis, 2012).

Family TRACHYLEBERIDIDAE Sylvester-Bradley, 1948 Genus CRONINOCYTHEREIS Yasuhara, Hunt, Okahashi, and Brandão, 2015

\section{Croninocythereis tridentiferae Yasuhara, Hunt, Oka-} hashi, and Brandão, 2015

(Pl. P4, fig. 7)

Croninocythereis tridentiferi [sic] Yasuhara, Hunt, Okahashi, and Brandão, 2015, p. 121, figs. 61I-J, 66E-I, 67A-F.

Stratigraphic distribution: Middle Eocene-lower Miocene (Yasuhara et al., 2015). The lowest occurrence is from the middle Eocene in DSDP Hole 21A, North Atlantic, whereas the highest occurrence is from the lower Miocene at DSDP Site 529, southeastern Atlantic (Yasuhara et al., 2015).

Remarks: Following the agreement in gender to form the species-group names (Article 31.2 of International Code of Zoological Nomenclature), tridentiferi, a masculine genitive, is replaced to tridentiferae, a feminine genitive.

Genus DUTOITELLA Dingle, 1981

Dutoitella mimica Dingle, 1981

(Pl. P5, fig. 1)

Dutoitella mimica Dingle 1981, p. 88, figs. 37F, 41A-F, 42AB, 43B-F, 44B; Majoran and Widmark, 1998, p. 854, fig. 3.9-3.11; Majoran and Dingle, 2001, p. 212, pl. 1, fig. 3; Majoran and Dingle, 2002, p. 147, fig. 3.1; Bergue and Nicolaidis, 2012, p. 52, fig. 3.1-3.3; Bergue et al., 2013, p. 29 , fig. $2 \mathrm{~K}$.

Dutoitella cf. mimica Dingle. Majoran et al. 1998, p. 66, pl. 2, fig. 10.

Dutoitella aff. mimica Dingle. Majoran et al. 1998, p. 66, pl. 3, fig. 10.

Dutoitella sp. 2. Rodriguez-Lazaro and Garcia-Zaraga, 1996, pl. 1, fig. 17.

Legitimocythere presequenta (Benson). Guernet and Bellier, 2000, p. 264, pl. 3, figs. 2-3.

? Dutoitella mimica Dingle. Yasuhara et al. 2015, p. 74, figs. 38C-F, 39A-D.

Stratigraphic distribution: Maastrichtian-Priabonian. Originally D. mimica is described from Maastrichtian sediments (Dingle, 1981). At Site 689, Southern Ocean and DSDP Site 327, this species is reported from Maastrichtian sediments (Majoran and Widmark, 1998; Majoran et al., 1998). It disappeared near the calcareous nannofossil Zone NP20/NP21 boundary of Martini (1971) (34.44 Ma) (Majoran and Dingle, 2002). In the Basque Basin, the species occurs from the middle Eocene sediments (Rodriguez-Lazaro and Garcia-Zaraga, 1996).

Remarks: Dutoitella mimica is similar to Dutoitella praeshusmi Coles and Whatley, 1989, in surface ornaments. D. mimica is distinguished from the latter species by having 
fewer tubercles along the dorsal margin, three tubercles on the postero-central area, and fewer tubercles on the anterocentral area. Yasuhara et al. (2015) regarded D. mimica of Majoran and Widmark (1998) as Dutoitella crassinodosa (Guernet, 1985). However the specimen of Majoran and Widmark (1998) has finer and more tubercles along the dorsal margin than $D$. crassinodosa with three tubercles along the margin.

\section{Genus PENNYELLA Neale 1974; emend. Yasuhara, Hunt, Okahashi, and Brandão, 2013}

\section{Pennyella sp.}

(P1. P5, figs. 3-6)

Description: Adult carapace robust and large in size (707 $\mu \mathrm{m}$ long). In external view, lateral outline subrectangular: anterior margin round; posterior margin round with apex near middle of valve; dorsal margin slightly curved; ventral margin curved, convex up near anterior one-third. Maximum length across apex of posterior margin; maximum height across antero-dorsal corner. Surface ornament with carina and tubercles. Anterior marginal rim formed by carina running from antero-dorsal corner to ventral margin. At least 16 tubercles on anterior marginal rim. Numerous tubercles cover the central area. Four superimposed blunt tubercles near postero-dorsal corner and in central and postero-central areas. Marginal denticles along all margins. In internal view, holamphidont-type hingement: in RV, round tooth and socket of anterior element; smooth median groove; large round tooth with small crenulation of posterior element. Anterior marginal frill and anterior and posterior marginal zones developed. V-shaped frontal muscle scar.

Remarks: The species has the following characteristics of the genus Pennyella: the holamphidont-type hingement, tubercled ornament, lateral shape (especially in antero- dorsal area and blunt posterior), ventral swelling, posterodorsal spine, and width of the inner lamella. This species is distinguished from $C$. tridentiferae by having surface ornaments with finer and higher-dense spines. This species is similar to Herrigocythere bathypteron (Coles and Whatley, 1989) in spiny surface ornaments but distinguished from $H$. bathypteron by more tubercles on the anterior marginal rim and finer and more tubercles on the antero-central and central areas.

\section{Genus TRACHYLEBERIDEA Bowen, 1953; emend.} Haskins, 1963

\section{Trachyleberidea sp.}

(Pl. P5, figs. 7, 8)

Description: Juvenile carapace robust and large (745 $\mu \mathrm{m}$ long). In external view, lateral outline subtrapezoidal: anterior margin round; posterior margin tapering, forming caudal process; dorsal and ventral margins slightly sinuous. Maximum length across caudal process; maximum height across antero-dorsal corner. Marginal denticles along anterior margin and lower part of posterior margin. Anterior marginal rim running to postero-ventral area. Perforate spine at terminal of ventral rim. Spine present at antero-dorsal corner. Surface ornaments with reticulation of trefoil celation and blunt muri. Reticulation on ventral area is flattened. In internal view, lophodont-type hingement: in LV, elongate socket of anterior element; straight smooth median bar; elongated half-round socket of posterior element. Anterior marginal zone narrow. Anterior marginal frill very well developed.

Remarks: Only one specimen was obtained from the samples. The specimen shares the reticulation of trefoil celation and blunt muri and the distinct ventral rim with Trachyleberidea mammidentata (van den Bold, 1946). The juvenile form possibly is of T. mammidentata. 